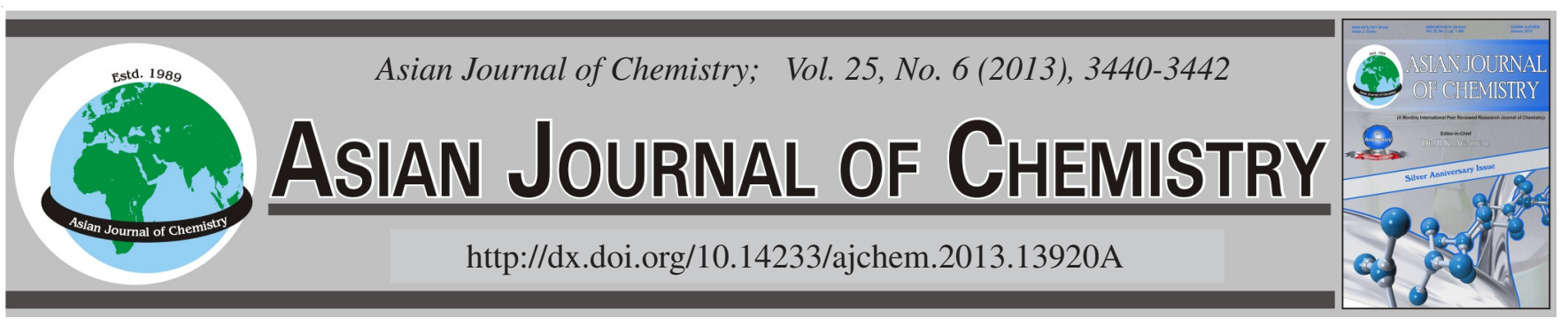

\title{
Synthesis and Crystal Structure of 4,4',6,6'-Tetrachloro-2,2'-[(1,4-butylene)dioxybis(nitrilmethylidyne)]diphenol
}

Li WAnG* ${ }^{*}$ XiU-YAn Dong, Li ZhaO and Yu-HuA YANG

School of Chemical and Biological Engineering, Lanzhou Jiaotong University, Lanzhou 730070, P.R. China

*Corresponding author: E-mail: wangli_78@126.com

(Received: 17 April 2012;

Accepted: 24 December 2012)

AJC-12609

\begin{abstract}
The compound 4,4',6,6'-tetrachloro-2,2'-[(1,4-butylene)dioxybis(nitrilmethylidyne) ]diphenol with the molecular formula $\mathrm{C}_{18} \mathrm{H}_{16} \mathrm{Cl}_{4} \mathrm{~N}_{2} \mathrm{O}_{4}$, was synthesized by the reaction of 3,5-dichloro-2-hydroxybenzaldehyde with 1,4-bis(aminooxy)butane in ethanol. The molecule is disposed about a crystallographic centre of symmetry and the molecule adopts an extended conformation where the two phenoldoxime moieties are apart from each other. There are strong $\mathrm{O}-\mathrm{H} \cdots \mathrm{N}$ intramolecular hydrogen bond and weak $\mathrm{C}-\mathrm{H} \cdots \mathrm{O}$ and $\mathrm{C}-\mathrm{H} \cdots \mathrm{Cl}$ intermolecular hydrogen bonds and strong intermolecular $\pi-\pi$ stacking interactions (the nearest benzene rings are parallel to that of another molecule, are $c a$. $2.512(2) \AA$ ), stabilizing the two dimensional structures of the present compound.
\end{abstract}

Key Words: Salen-type bisoxime compound, Synthesis, Crystal structure, Supramolecular interaction.

\section{INTRODUCTION}

Salen-type compounds have been intensively used as versatile chelating ligands in the formation of transition metal complexes ${ }^{1}$. Some of them or their metal complexes are used in various organic reaction processes as catalysts ${ }^{2}$, models of reaction centers of metalloenzymes ${ }^{3}$, have fascinating magnetic properties $^{4}$ and are non-linear optical materials ${ }^{5}$. They can also be used as biological models in understanding the structure of biomolecules and biological processes ${ }^{6,7}$. Most of their important features of these compounds are their preparative accessibility, diversity and structural variability, which make them more attractive. Some salen-type bisoxime derivatives, such as 2,2'[(1,4-butylene)dioxybis(nitrilomethylidyne)] dinaphthol ${ }^{8}, 4,4^{\prime}-$ dibromo-2,2'-[ethylenedioxybis (nitrilomethylidyne)]diphenol ${ }^{9}$, 4,4'-dibromo-2,2'-[(1,3-propylene)dioxybis(nitrilo-methylidyne) diphenol $^{10}, 2,2^{\prime}$-[(1,4-butylene)dioxybis-(nitrilomethylidyne)]diphenol ${ }^{11}, 4,4^{\prime}$-dichloro-2,2'-[(1,4-butylene)dioxybis(nitrilomethylidyne)]diphenol ${ }^{12}, 4,4 ', 6,6^{\prime}$-tetra(tertbutyl)-2,2'-[(1,4-butylene)dioxybis(nitrilomethylidyne)]diphenol ${ }^{13}, 2,2^{\prime}-[(1,4$-butylene)dioxybis(nitriloethylidyne)]diphenol $^{14}, 2,2^{\prime}$-[(propane-1,3-diyldioxy)bis-(nitrilomethylidyne)]diphenol ${ }^{15}$ and 5,5'-bis(diethylamino)-2,2'-[ethylenedioxybis(nitrilomethylidyne)]dipheno ${ }^{16}$ have been studied in recent years. In this paper, a new bisoxime compound, 4,4',6,6'tetrachloro-2,2'-[(1,4-butylene)dioxybis-(nitrilmethylidyne)]diphenol was synthesized and characterized structurally.

\section{EXPERIMENTAL}

2-Hydroxybenzaldehyde was purchased from Alfa Aesar and used without further purification. 1,4-bis(Aminooxy)butane was synthesized according to an analogous method reported earlier ${ }^{3}$. The other reagents and solvents were analytical grade reagents from Tianjin Chemical Reagent Factory. C, $\mathrm{H}$ and $\mathrm{N}$ analyses were carried out with a $\mathrm{GmbH}$ VariuoEL V3.00 automatic elemental analyzer. IR spectra in the range $4000-400 \mathrm{~cm}^{-1}$ were recorded on a VERTEX70 FTIR spectrophotometer using $\mathrm{KBr}$ pellets. The ${ }^{1} \mathrm{H}$ NMR spectra were recorded on a Mercury-400BB spectrometer at room temperature using $\mathrm{CDCl}_{3}$ as solvent. X-Ray single crystal structure was determined on a Bruker Smart 1000 CCD area detector. Melting points were measured by the use of a microscopic melting point apparatus made in Beijing Taike Instrument Limited Company and the thermometer was uncorrected.

\section{General procedure}

4,4',6,6' -Tetrachloro-2,2' -[(1,4-butylene)dioxybis(nitrilmethylidyne)]diphenol: To an ethanol solution $(6 \mathrm{~mL})$ of 3,5-dichloro-2-hydroxybenzaldehyde $(573.0 \mathrm{mg}, 3.00$ mmol) was added an ethanol (2 mL) solution of 1,4bis(aminooxy)butane (180.1 mg, $1.50 \mathrm{mmol})$. The mixture solution was stirred at $328 \mathrm{~K}$ for $4 \mathrm{~h}$. The precipitate was filtered and washed successively with ethanol and ethanol/ hexane (1:4), respectively. The product was dried under vacuum and to yield $480.30 \mathrm{mg}$ of the title compound. Yield, 
$68.7 \%$. m.p. 475-476 K. Colourless needle-shaped single crystals suitable for X-ray diffraction studies were obtained after four weeks by slow evaporation from an tetrahydrofuran/ ethyl acetate/ethanol (2:1:2) solution of 4,4'6,6'-tetrachloro2,2'-[(1,4-butylene)dioxybis(nitrilmethylidyne)]diphenol. Anal. calcd. (\%) for: $\mathrm{C}_{18} \mathrm{H}_{16} \mathrm{Cl}_{4} \mathrm{~N}_{2} \mathrm{O}_{4}$ : C, 46.45; H, 3.40; N, 5.87. Found (\%): C, 46.38; H, 3.46; N, 6.01.

X-Ray structure determination: The single crystal of the title compound, with approximate dimensions of $0.45 \mathrm{~mm}$ $\times 0.40 \mathrm{~mm} \times 0.17 \mathrm{~mm}$ was placed on a Bruker Smart 1000 diffractmeter equipped with Apex CCD area detector. The diffraction data were collected using a graphite monochromated $\operatorname{MoK}_{\alpha}$ radition $(\lambda=0.71073 \AA$ ) at $293(2) \mathrm{K}$. The structure was solved by using the program SHELXS-97 and Fourier difference techniques and refined by full-matrix least-squares method on $\mathrm{F}^{2}$ using SHELXL-97. Details of the data collection and refinements of title compound are given in Table-1. The non-hydrogen atoms were refined anisotropically. Hydrogen atoms were added theoretically. CCDC: 684099.

\begin{tabular}{|c|c|}
\hline \multicolumn{2}{|c|}{$\begin{array}{c}\text { TABLE-1 } \\
\text { CRYSTAL DATA AND REFINEMENT } \\
\text { PARAMETERS FOR THE TITLE COMPOUND }\end{array}$} \\
\hline Empirical formula & $\mathrm{C}_{18} \mathrm{H}_{16} \mathrm{~N}_{2} \mathrm{O}_{4} \mathrm{Cl}_{4}$ \\
\hline Formula weight & 466.13 \\
\hline Temperature & 293(2) K \\
\hline Wavelength & $0.71073 \AA$ \\
\hline Crystal system & Triclinic \\
\hline Space group & $\mathrm{P}-1$ \\
\hline Cell dimensions & $\begin{array}{l}a=4.2525(5) \AA, b=7.9844(10) \AA, \\
c=14.3333(19) \AA, \alpha=74.5330(10)^{\circ}, \\
\beta=84.330(6)^{\circ}, \gamma=80.533(2)^{\circ}\end{array}$ \\
\hline Volume & $461.88(10) \AA^{3}$ \\
\hline $\mathrm{Z}$ & 1 \\
\hline Density (calculated) & $1.676 \mathrm{mg} / \mathrm{m}^{3}$ \\
\hline Absorption coefficient & $0.671 \mathrm{~mm}^{-1}$ \\
\hline $\mathrm{F}_{(000)}$ & 238 \\
\hline Index ranges & $-5 \leq \mathrm{h} \leq 4,-9 \leq \mathrm{k} \leq 4,-16 \leq 1 \leq 16$ \\
\hline Reflections collected/unique & $1819 / 1555\left[\mathrm{R}_{\text {(int) }}=0.0387\right]$ \\
\hline Independent reflections & 1395 \\
\hline Data/restraints/parameters & $1555 / 0 / 128$ \\
\hline Goodness of fit indicator & 1.046 \\
\hline $\mathrm{R}[\mathrm{I}>2 \sigma(\mathrm{I})]$ & $\mathrm{R}_{1}=0.0664, \mathrm{wR}_{2}=0.1252$ \\
\hline Largest diff. peak and hole & 0.427 and -0.419 e. $\AA$ \\
\hline
\end{tabular}

\section{RESULTS AND DISCUSSION}

$\mathrm{X}$-Ray crystallographic analysis revealed the crystal structure of the title compound. And the structure is shown in Fig. 1. Selected bond distances and angles are listed in Table-2. The single crystal structure of the title compound is built up by only the $\mathrm{C}_{18} \mathrm{H}_{16} \mathrm{Cl}_{4} \mathrm{~N}_{2} \mathrm{O}_{4}$ moleculars (Fig. 1), in which all bond lengths are in normal ranges. The X-ray crystallography reveals the title compound crystallizes in the triclinic system, space group P-1 with a = 4.2525(5) $\mathrm{A}, \mathrm{b}=7.9844(10) \AA, \mathrm{c}=$ 14.3333(19) $\AA, \alpha=74.5330(10)^{\circ}, \beta=84.330(2)^{\circ}, \gamma=$ $80.533(2)^{\circ}$ and $\mathrm{Z}=1$. The molecule is disposed about a crystallographic centre of symmetry and the molecule adopts an extended conformation where the two phenoldoxime moieties are apart from each other. The distance (1.365(2) ^) of two parallel benzene rings in the title compound is shorter than

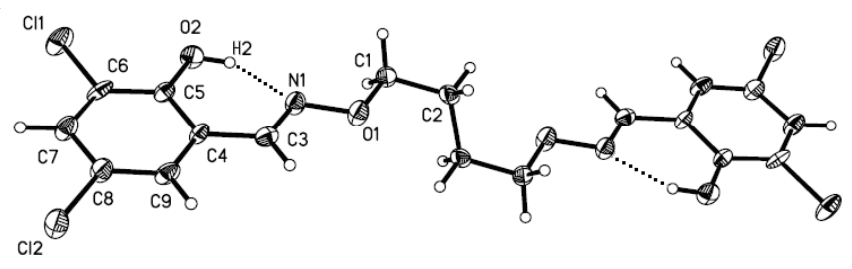

Fig. 1. Molecule structure of the title compound with atom numbering scheme. Displacement ellipsoids for non-hydrogen atoms are drawn at the $30 \%$ probability level

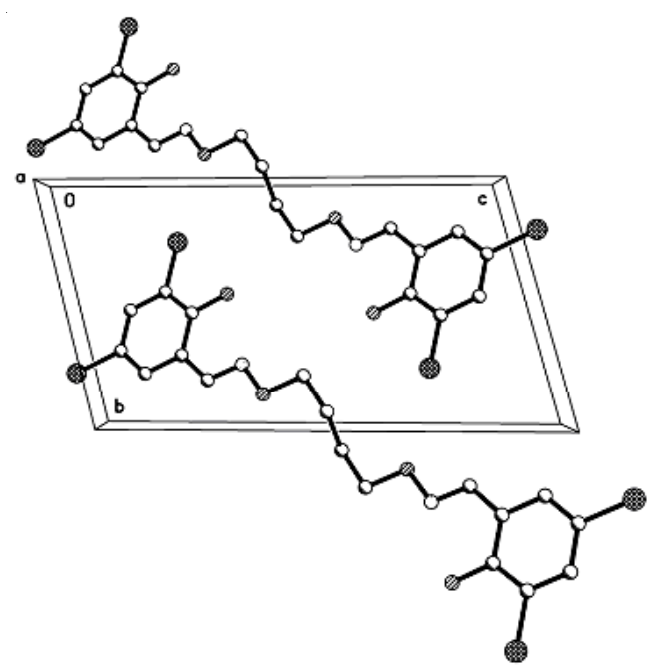

Fig. 2. Molecular packing arrangement in the unit cell

TABLE-2

SELECTED BOND LENGTHS (̊̊) AND ANGLES $\left(^{\circ}\right)$ FOR THE TITLE COMPOUND

\begin{tabular}{cccccc}
\hline Bond & Lengths & Bond & Lengths & Bond & Lengths \\
\hline $\mathrm{Cl}(1)-\mathrm{C}(6)$ & $1.702(8)$ & $\mathrm{O}(2)-\mathrm{C}(5)$ & $1.315(9)$ & $\mathrm{C}(4)-\mathrm{C}(5)$ & $1.397(10)$ \\
$\mathrm{Cl}(2)-\mathrm{C}(8)$ & $1.714(9)$ & $\mathrm{C}(1)-\mathrm{C}(2)$ & $1.443(11)$ & $\mathrm{C}(5)-\mathrm{C}(6)$ & $1.349(12)$ \\
$\mathrm{N}(1)-\mathrm{C}(3)$ & $1.251(10)$ & $\mathrm{C}(2)-\mathrm{C}(2)$ & $1.532(16)$ & $\mathrm{C}(6)-\mathrm{C}(7)$ & $1.340(12)$ \\
$\mathrm{N}(1)-\mathrm{O}(1)$ & $1.365(9)$ & $\mathrm{C}(3)-\mathrm{C}(4)$ & $1.407(11)$ & $\mathrm{C}(7)-\mathrm{C}(8)$ & $1.378(12)$ \\
$\mathrm{O}(1)-\mathrm{C}(1)$ & $1.402(9)$ & $\mathrm{C}(4)-\mathrm{C}(9)$ & $1.367(11)$ & $\mathrm{C}(8)-\mathrm{C}(9)$ & $1.326(12)$ \\
\hline Bond & Angles & $\mathrm{B}(9)$ & Angles & Bond & Angles \\
\hline $\mathrm{C}(3)-\mathrm{N}(1)-\mathrm{O}(1)$ & $110.8(7)$ & $\mathrm{C}(5)-\mathrm{C}(4)-\mathrm{C}(3)$ & $122.1(7)$ & $\mathrm{C}(5)-\mathrm{C}(6)-\mathrm{Cl}(1)$ & $118.8(6)$ \\
$\mathrm{N}(1)-\mathrm{O}(1)-\mathrm{C}(1)$ & $109.6(6)$ & $\mathrm{O}(2)-\mathrm{C}(5)-\mathrm{C}(6)$ & $119.6(7)$ & $\mathrm{C}(6)-\mathrm{C}(7)-\mathrm{C}(8)$ & $118.2(8)$ \\
$\mathrm{O}(1)-\mathrm{C}(1)-\mathrm{C}(2)$ & $105.9(6)$ & $\mathrm{O}(2)-\mathrm{C}(5)-\mathrm{C}(4)$ & $121.7(7)$ & $\mathrm{C}(9)-\mathrm{C}(8)-\mathrm{C}(7)$ & $122.4(8)$ \\
$\mathrm{C}(1)-\mathrm{C}(2)-\mathrm{C}(2)$ & $115.6(10)$ & $\mathrm{C}(6)-\mathrm{C}(5)-\mathrm{C}(4)$ & $118.6(7)$ & $\mathrm{C}(9)-\mathrm{C}(8)-\mathrm{Cl}(2)$ & $119.6(7)$ \\
$\mathrm{N}(1)-\mathrm{C}(3)-\mathrm{C}(4)$ & $120.5(7)$ & $\mathrm{C}(7)-\mathrm{C}(6)-\mathrm{C}(5)$ & $121.9(8)$ & $\mathrm{C}(7)-\mathrm{C}(8)-\mathrm{Cl}(2)$ & $118.0(7)$ \\
$\mathrm{C}(9)-\mathrm{C}(4)-\mathrm{C}(5)$ & $119.8(7)$ & $\mathrm{C}(7)-\mathrm{C}(6)-\mathrm{Cl}(1)$ & $119.3(7)$ & $\mathrm{C}(8)-\mathrm{C}(9)-\mathrm{C}(4)$ & $119.1(8)$ \\
$\mathrm{C}(9)-\mathrm{C}(4)-\mathrm{C}(3)$ & $118.1(7)$ & - & - & - & - \\
\hline
\end{tabular}


the distance $(2.028(3) \AA$ ) of parallel benzene ring planes in 4,4'-dichloro-2,2'-[(1,4-butylene)dioxybis (nitrilomethylidyne)]diphenol ${ }^{12}$. The oxime, chloro groups and phenolic alcohols have anticonformation, which is similar to what is observed in our previously reported salen-type bisoxime of 2,2'-[(1,4butylene)dioxybis(nitriloethylidyne)] diphenol ${ }^{14}$. There are strong $\mathrm{O}-\mathrm{H} \cdots \mathrm{N}$ intramolecular hydrogen bond between $\mathrm{N} 1$ atom and $\mathrm{O} 2$ atom of hydroxyl. Three $\mathrm{C}$ atoms, one $\mathrm{N}$ atom, one $\mathrm{O}$ atom and one $\mathrm{H}$ atom generate a six-membered ring through hydrogen bonds $(\mathrm{d}(\mathrm{O} 2-\mathrm{H} 2)=0.82 \AA, \mathrm{d}(\mathrm{H} 2 \cdots \mathrm{N} 1)=$ $\left.1.83 \AA, \mathrm{d}(\mathrm{O} 2 \cdots \mathrm{N} 1)=2.555(3) \AA, \angle \mathrm{O} 2-\mathrm{H} 2 \cdots \mathrm{N} 1=146^{\circ}\right)$, which with weak $\mathrm{C}-\mathrm{H} \cdots \mathrm{O}$ and $\mathrm{C}-\mathrm{H} \cdots \mathrm{Cl}$ intermolecular hydrogen bonds and strong intermolecular pai-pai stacking interactions (the nearest benzane rings are parallel to that of another molecule, are $c a$. 2.512(2) §), stabilizing the two dimensional structures of the title compound ${ }^{17}$.

\section{ACKNOWLEDGEMENTS}

This work was supported by the Foundation of Preparative Research of Jin-Chuan Corporation (Grant No. 420032), which is gratefully acknowledged.

\section{REFERENCES}

1. W.K. Dong, G. Wang, S.S. Gong, J.F. Tong, Y.X. Sun and X.H. Gao, Transition Met. Chem., 37, 271 (2012).
2. N.S. Venkataramanan, G. Kuppuraj and S. Rajagopal, Coord. Chem. Rev., 249, 1249 (2005).

3. T. Katsuki, Coord. Chem. Rev., 140, 189 (1995).

4. J.P. Costes, F. Dahan and A. Dupuis, Inorg. Chem., 39, 165 (2000).

5. P.G. Lacroix, Eur. J. Inorg. Chem., 339 (2001).

6. R. Atkins, G. Brfwer, E. Kokto, G.M. Mockler and E. Sinn, Inorg. Chem., 24, 128 (1985).

7. D.A. Atwood, Coord. Chem. Rev., 165, 267 (1997).

8. W.K. Dong, J.G. Duan, H.L. Wu, J.Y. Shi and T.Z. Yu, New Cryst. Struct., 221, 555 (2006).

9. W.K. Dong and J.H. Feng, Acta Cryst., E62, 3577 (2006).

10. W.K. Dong, J.H. Feng and X.Q. Yang, Z. Kristallogr. New Cryst. Struct., 221, 447 (2006).

11. W.K. Dong, J.G. Duan, C.M Dong, Z.L. Ren and J.Y. Shi, Z. Kristallogr. New Cryst. Struct., 222, 327 (2007).

12. W.K. Dong, J.Y. Shi, Y.X. Sun, L. Wang, J.G. Duan, J.K. Zhong and L. Xu, Anal. Sci., 23, 167 (2007).

13. W.K. Dong, J.H. Feng and X.Q. Yang, Z. Kristallogr. New Cryst. Struct., 222, 50 (2007).

14. W.K. Dong, X.N. He, C.M. Dong, L. Wang, J.K. Zhong, X. Chen and T.Z. Yu, Z. Kristallogr. New Cryst. Struct., 222, 289 (2007).

15. J.G. Duan, C.M. Dong, J.Y. Shi, L. Wu and W.K. Dong, Acta Cryst., E63, 2704 (2007).

16. Y.P. Zhang, G.H. Liu, J.Y. Shi, L. Xu and W.K. Dong, Acta Cryst., E63, 3852 (2007).

17. W.K. Dong, G. Wang, Y.X. Sun, X.Y. Dong and X.H. Gao, Z. Naturforsch., 67b, 17 (2012). 